Repository Layout and Required

Ventilation Trade Studies in Clay/Shale using the DSEF Thermal Analytical Model

H. R. Greenberg, J. A. Blink, T. A. Buscheck

June 12, 2013 
This document was prepared as an account of work sponsored by an agency of the United States government. Neither the United States government nor Lawrence Livermore National Security, LLC, nor any of their employees makes any warranty, expressed or implied, or assumes any legal liability or responsibility for the accuracy, completeness, or usefulness of any information, apparatus, product, or process disclosed, or represents that its use would not infringe privately owned rights. Reference herein to any specific commercial product, process, or service by trade name, trademark, manufacturer, or otherwise does not necessarily constitute or imply its endorsement, recommendation, or favoring by the United States government or Lawrence Livermore National Security, LLC. The views and opinions of authors expressed herein do not necessarily state or reflect those of the United States government or Lawrence Livermore National Security, LLC, and shall not be used for advertising or product endorsement purposes.

This work performed under the auspices of the U.S. Department of Energy by Lawrence Livermore National Laboratory under Contract DE-AC52-07NA27344. 


\title{
Repository layout and Required Ventilation Trade Studies in Clay/Shale Using the DSEF Thermal Analytical Model
}

\author{
Used Fuel Disposition Campaign \\ Repository Science/Thermal Load Management \& Design Concepts \\ (Work Package FT-13LL080401)
}

Level 4 Milestone (M4): M4FT-13LL0804012

(Continue Thermal Analyses for Disposal Concepts)

Harris R. Greenberg, James A. Blink, and Thomas A. Buscheck Lawrence Livermore National Laboratory

June 2013

LLNL-TR-638880 
This document was prepared as an account of work sponsored by an agency of the United States government. Neither the United States government nor Lawrence Livermore National Security, LLC, nor any of their employees makes any warranty, expressed or implied, or assumes any legal liability or responsibility for the accuracy, completeness, or usefulness of any information, apparatus, product, or process disclosed, or represents that its use would not infringe privately owned rights. Reference herein to any specific commercial product, process, or service by trade name, trademark, manufacturer, or otherwise does not necessarily constitute or imply its endorsement, recommendation, or favoring by the United States government or Lawrence Livermore National Security, LLC. The views and opinions of authors expressed herein do not necessarily state or reflect those of the United States government or Lawrence Livermore National Security, LLC, and shall not be used for advertising or product endorsement purposes.

This work performed under the auspices of the U.S. Department of Energy by Lawrence Livermore National Laboratory under Contract DE-AC52-07NA27344. 
Table of Contents

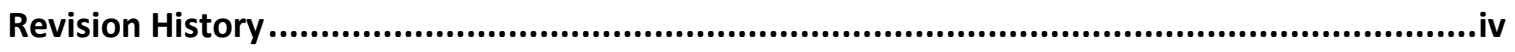

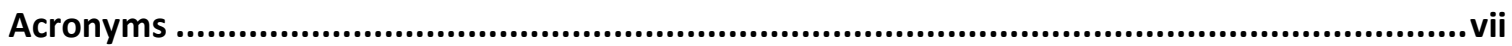

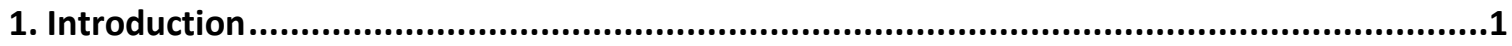

2. Trade Study Performed in 2013 IHLRWM Conference Paper ...............................................3

3. Additional Base Cases Evaluated in this Report .............................................................8

4. Balanced Heat Source Contribution Evaluation.................................................................12

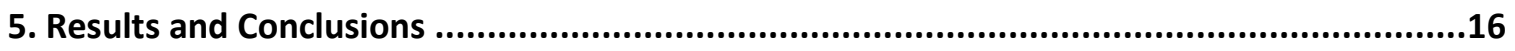

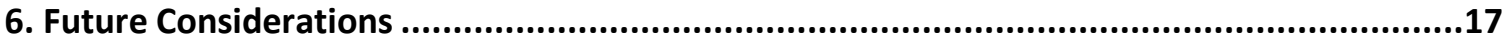

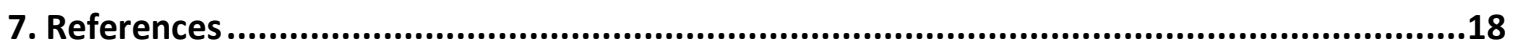

Appendix A - Mathcad Iterative Convergence Model................................................... A-1

Appendix B - Excavation Length versus Waste Package and Drift Spacing ........................... B-1 


\section{Revision History}

\section{LLNL-TR-638880 (June 2013)}

- Original document. 
Tables

Table 1 - Summary of clay/shale repository design cases evaluated in the 2013 IHLRWM Conference paper.

Table 2 - Required ventilation time for cases analyzed in the 2013 IHLRWM Conference paper . 5

Table 3- Color code criterion for heat source contributions assumed for balancing the tradeoff between excavation/backfill volumes and required ventilation duration.................................... 8

Table 4 - Case numbers and required ventilation time results for new cases evaluated in clay/shale.

Table 5 - Percentage contributions to peak wall temperature from the central WP, adjacent drifts, and adjacent WPs for clay/shale ................................................................................... 9

Table 6 - DSEF cost calculation input data for excavation length and volume calculations........... 2

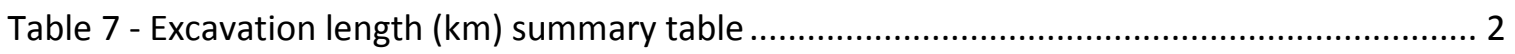


Figures

Figure 1 - Graphical Results from the 2013 IHLRWM paper for 21-PWR and 32-PWR waste packages

Figure 2 - Ventilation time required for a 32-PWR waste package stream in clay/shale - 2013 IHLRWM paper results.

Figure 3- Required ventilation time as a function of temperature acceptance criterion, waste package spacing, and drift spacing.

Figure 4 - Balanced heat source contribution cases for $T C=100,120$, and $140^{\circ} \mathrm{C}$ as a function of waste package and drift spacing.

Figure 5- Required ventilation time in Clay/Shale for TC $=100^{\circ} \mathrm{C}$ versus WP and drift spacing . 14

Figure 6- Required ventilation time in Clay/Shale for TC $=120^{\circ} \mathrm{C}$ versus WP and drift spacing . 14

Figure 7 - Required ventilation time in Clay/Shale for TC $=140^{\circ} \mathrm{C}$ versus WP and drift spacing 15

Figure 8 - Normalized repository excavation length versus drift and WP spacing for 32-PWR waste packages. 


\section{Acronyms}

21P

32P

BU

DOE

DSEF

Dr Sp

EBS

FY

GWd

GWd/MT

IHLRWM

LLNL

MM

MT

MTIHM

MTHM

MTU

NE

PWR

TC

t-store

UFD

WP

WP Sp
21 assembly PWR (21-PWR) waste package

32 assembly PWR (32-PWR) waste package

Burnup (GWd/MT)

U.S. Department of Energy

Disposal Systems Evaluation Framework

Drift / borehole spacing ( $\mathrm{m})$

Engineered Barriers System

Fiscal Year

Gigawatt days

Gigawatt (thermal) - days per Metric Ton

International High-Level Radioactive Waste Management (Conference)

Lawrence Livermore National Laboratory

Million

Metric Ton (used interchangeably with MTHM, MTIHM and MTU)

Metric Ton of Initial Heavy Metal

Metric Tons of Heavy Metal

Metric Tons of Uranium

DOE-Nuclear Energy

Pressurized Water Reactor

Temperature acceptance criterion $\left({ }^{\circ} \mathrm{C}\right)$

Surface storage time (years), sometimes referred to using the Mathcad variable name (t_store)

Used Fuel Disposition

Waste Package

Waste package spacing $(\mathrm{m})$ 


\section{Introduction}

This Lawrence Livermore National Laboratory (LLNL) report is a Level 4 milestone deliverable M4FT-13LL0804012, which is a supporting document to a Level 4 Sandia National Laboratories milestone, M4FT-13SN0804036, Collaborative Report on Disposal Concepts.

The trade studies presented in this report were facilitated by the results of a series of thermal modeling and thermal performance parametric sensitivity studies developed over a two-year period in Sutton (2011), Greenberg (2012a and 2012b), and utilized in Hardin (2011 and 2012) that evaluated both "enclosed" and "open" repository design concepts.

\section{Objective:}

Extend the LLNL 2013 International High-Level Radioactive Waste Management (IHLRWM) conference paper on required ventilation time in a clay/shale repository design concept, as a function of thermal acceptance criterion (TC), WP spacing, and drift spacing for large (32-PWR) waste packages. Larger repository spacing designs are included to provide technical backup data for design concepts with larger WP and drift spacing. Specifically, this report extended the analyzed maximum waste package spacing from 20 to $30 \mathrm{~m}$, and the maximum drift spacing from 60 to $90 \mathrm{~m}$.

\section{Assumptions:}

- $\quad$ Clay/shale with host rock thermal conductivity of $1.75 \mathrm{~W} / \mathrm{m}-\mathrm{K}$

- $\quad 32-P W R$ waste packages with burnup of $40 \mathrm{GWd} / \mathrm{MT}$

- 50 year surface storage

- 150 years maximum acceptable ventilation time (after the end of surface storage)

- Three alternative temperature acceptance criterion for clay $/$ shale, $\mathrm{TC}=100^{\circ} \mathrm{C}$, $120^{\circ} \mathrm{C}$, and $140^{\circ} \mathrm{C}$ at the drift wall.

\section{Approach:}

The DSEF Mathcad thermal analytical component is used to analyze the design cases. A variation on the Mathcad parametric study version is developed to add an iterative solution programming loop to identify required ventilation time (See Appendix A).

Temperature buildup at a given waste package location in a drift is the result of contributions from three generic sources of heat: (1) the adjacent drifts (lateral neighbors), (2) the adjacent waste packages within that drift (axial neighbors), and (3) that waste package itself. A unique feature of the Mathcad analytical model is developed to quantify these three generic heat source contributions to temperature buildup, which is evaluated with regards to peak drift wall temperature. This new feature is applied to a repository layout optimization methodology that seeks to balance these temperature buildup contributions in a manner that makes for an optimal repository layout, as defined below. 
This temperature buildup balancing approach, called the "sweet spot" approach, is based on the following rationale. Optimal thermal management balances efficient dissipation of temperature buildup in the repository rock against removal of waste package heat through ventilation. On one end of the spectrum, waste packages can be spread out over a large lineal extent of emplacement drift so that heat dissipation can be spread out, which reduces maximum temperature buildup. The tradeoff for this approach is that it increases the excavation and backfill volumes (and repository area), while it reduces required ventilation duration. On the other end of the spectrum, waste packages can be closely spaced, which places heavier reliance on heat removal via ventilation to meet compliance temperature criterion. While this approach reduces the excavation and backfill volumes, it also increases required ventilation duration.

Repository layouts that result in balanced temperature buildup contributions from these three generic heat sources are those that balance effective heat dissipation in the repository rock with heat removal via ventilation. We show later in this report that this approach can be an effective means of identifying a range of repository layouts that result in an optimal balance between excavation/backfill volumes and required ventilation duration.

It should be noted that other parameters may also be used in this type of analysis, including drift diameter, location of the temperature compliance point, waste package capacity, burnup, and thermal conductivity of the backfill. For the purpose of this report, large waste packages of moderate burnup were selected, and the temperature compliance criterion was applied at the rock wall. 


\section{Trade Study Performed in 2013 IHLRWM Conference Paper}

In a paper presented in May 2013 at the International High-Level Radioactive Waste Management (IHLRWM) conference in Albuquerque, NM (Greenberg 2013a), design tradeoffs for a clay/shale repository were evaluated using the Disposal Systems Evaluation Framework (DSEF) developed at LLNL (Greenberg 2013b).

Table 1 shows the case numbers originally evaluated for selected combinations of waste package size, drift spacing, waste package spacing, and temperature acceptance criterion. Blank cells represent cases that were not analyzed because workable solutions (short enough ventilation times) were identified with more closely spaced waste packages and/or drifts. Because workable cases were identified with 50 years of surface storage, additional cases based on 100 years of surface storage were not evaluated.

Table 2 shows the required ventilation time results for the cases evaluated.

The design trade study in Greenberg 2013a found combinations of closure time and waste package capacity that met specified thermal constraints in clay/shale. Figure 1 shows the locus of these points as a set of design curves with the space on one side of the curves having design margin. A family of design curves can be developed as other parameters are varied, including emplacement mode, spacing of waste packages and drifts/boreholes, ventilation efficiency and duration, and thermal constraint. Ultimately, the repository design tradeoffs quantified by these families of curves are themselves inputs to the larger cost/performance tradeoffs to specify the configuration of the overall waste management system, including consolidated interim storage and repackaging.

Figure 2 presents a stacked bar depiction of the 45 and $60 \mathrm{~m}$ drift spacing data as Figure 1 , showing the ventilation time required for 32-PWR waste packages with three alternative temperature acceptance criterion, two alternative drift spacings, and three alternative waste package spacings. 
Table 1 - Summary of clay/shale repository design cases evaluated in the 2013 IHLRWM Conference paper

\begin{tabular}{|c|c|c|c|c|c|c|c|c|c|c|c|}
\hline \multirow{2}{*}{\multicolumn{3}{|c|}{$\begin{array}{c}\text { Original Case Numbers } \\
\text { Open mode concept in } \\
\text { clay/shale } \\
40-G W d / M T \text { SNFA }\end{array}$}} & \multirow{2}{*}{\multicolumn{3}{|c|}{$\begin{array}{c}\text { 12-PWR waste package } \\
\text { DSEF cases } 221 \text { (t-store 50) } \\
\text { and } 222 \text { (t-store 100) } \\
\text { Waste Package Spacing, m }\end{array}$}} & \multirow{2}{*}{\multicolumn{3}{|c|}{$\begin{array}{l}\text { 21-PWR waste package } \\
\text { DSEF cases } 225 \text { (t-store 50) } \\
\text { and } 226 \text { (t-store 100) } \\
\text { Waste Package Spacing, m }\end{array}$}} & \multirow{2}{*}{\multicolumn{3}{|c|}{$\begin{array}{c}\text { 32-PWR waste package } \\
\text { DSEF cases } 229 \text { (t-store 50) } \\
\text { and } 230 \text { (t-store 100) } \\
\text { Waste Package Spacing, m }\end{array}$}} \\
\hline & & & & & & & & & & & \\
\hline $\mathrm{TC}$ & Dr Sp, $m$ & t-store, yr & 10 & 15 & 20 & 10 & 15 & 20 & 10 & 15 & 20 \\
\hline 100 & 30 & 50 & $221-1$ & & & $225-1$ & $225-10$ & $225-19$ & $229-1$ & $229-10$ & $229-19$ \\
\hline 100 & 30 & 100 & $222-1$ & & & $226-1$ & & & $230-1$ & & \\
\hline 100 & 45 & 50 & $221-2$ & & & $225-2$ & $225-11$ & $225-20$ & $229-2$ & $229-11$ & $229-20$ \\
\hline 100 & 45 & 100 & $222-2$ & & & $226-2$ & & & $230-2$ & & \\
\hline 100 & 60 & 50 & $221-3$ & & & $225-3$ & $225-12$ & $225-21$ & $229-3$ & $229-12$ & $229-21$ \\
\hline 100 & 60 & 100 & $222-3$ & & & $226-3$ & & & $230-3$ & & \\
\hline 120 & 30 & 50 & $221-4$ & & & $225-4$ & $225-13$ & $225-22$ & $229-4$ & $229-13$ & $229-22$ \\
\hline 120 & 30 & 100 & $222-4$ & & & $226-4$ & & & $230-4$ & & \\
\hline 120 & 45 & 50 & $221-5$ & & & $225-5$ & $225-14$ & $225-23$ & $229-5$ & 229-14 & $229-23$ \\
\hline 120 & 45 & 100 & $222-5$ & & & $226-5$ & & & $230-5$ & & \\
\hline 120 & 60 & 50 & $221-6$ & & & $225-6$ & $225-15$ & $225-24$ & $229-6$ & $229-15$ & $229-24$ \\
\hline 120 & 60 & 100 & $222-6$ & & & $226-6$ & & & $230-6$ & & \\
\hline 140 & 30 & 50 & $221-7$ & & & $225-7$ & $225-16$ & $225-25$ & $229-7$ & $229-16$ & $229-25$ \\
\hline 140 & 30 & 100 & $222-7$ & & & $226-7$ & & & $230-7$ & & \\
\hline 140 & 45 & 50 & & & & $225-8$ & $225-17$ & $225-26$ & $229-8$ & $229-17$ & $229-26$ \\
\hline 140 & 45 & 100 & & & & $226-8$ & & & $230-8$ & & \\
\hline 140 & 60 & 50 & & & & $225-9$ & $225-18$ & $225-27$ & $229-9$ & $229-18$ & $229-27$ \\
\hline 140 & 60 & 100 & & & & $226-9$ & & & $230-9$ & & \\
\hline
\end{tabular}

Note-Case numbers identified in this table were analyzed and summarized in the tables and figures of Greenberg 2013a. 
Table 2 - Required ventilation time for cases analyzed in the 2013 IHLRWM Conference paper

\begin{tabular}{|c|c|c|c|c|c|c|c|c|c|c|c|}
\hline \multirow{2}{*}{\multicolumn{3}{|c|}{$\begin{array}{c}\text { Required Ventilation Time (yr) } \\
\text { to meet Temperature Criterion } \\
\text { Open mode concepts in } \\
\text { clay/shale } \\
40-\mathrm{GWd} / \mathrm{MT} \text { SNFA }\end{array}$}} & \multirow{2}{*}{\multicolumn{3}{|c|}{$\begin{array}{c}\text { 12-PWR waste package } \\
\text { DSEF cases } 221 \text { (t-store 50) } \\
\text { and } 222 \text { (t-store 100) } \\
\text { Waste Package Spacing, m }\end{array}$}} & \multirow{2}{*}{\multicolumn{3}{|c|}{$\begin{array}{c}\text { 21-PWR waste package } \\
\text { DSEF cases } 225 \text { (t-store 50) and } \\
226 \text { (t-store 100) }\end{array}$}} & \multirow{2}{*}{\multicolumn{3}{|c|}{$\begin{array}{c}\text { 32-PWR waste package } \\
\text { DSEF cases } 229 \text { (t-store 50) } \\
\text { and } 230 \text { (t-store 100) } \\
\text { Waste Package Spacing, m }\end{array}$}} \\
\hline & & & & & & & & & & & \\
\hline $\mathrm{TC}$ & Dr Sp, m & t-store, yr & 10 & 15 & 20 & 10 & 15 & 20 & 10 & 15 & 20 \\
\hline 100 & 30 & 50 & 116 & & & 683 & 310 & 125 & 1450 & 800 & 500 \\
\hline 100 & 30 & 100 & 40 & & & 600 & & & 1350 & & \\
\hline 100 & 45 & 50 & 19 & & & 235 & 100 & 42 & 950 & 490 & 275 \\
\hline 100 & 45 & 100 & 0 & & & 186 & & & 850 & & \\
\hline 100 & 60 & 50 & 11 & & & 160 & 53 & 35 & 660 & 300 & 145 \\
\hline 100 & 60 & 100 & 0 & & & 82 & & & 560 & & \\
\hline 120 & 30 & 50 & 20 & & & 400 & 108 & 30 & 950 & 485 & 270 \\
\hline 120 & 30 & 100 & 0 & & & 320 & & & 800 & & \\
\hline 120 & 45 & 50 & 0 & & & 135 & 27 & 12 & 590 & 240 & 90 \\
\hline 120 & 45 & 100 & 0 & & & 60 & & & 500 & & \\
\hline 120 & 60 & 50 & 0 & & & 53 & 20 & 9 & 347 & 100 & 62 \\
\hline 120 & 60 & 100 & 0 & & & 0 & & & 250 & & \\
\hline 140 & 30 & 50 & 0 & & & 210 & 30 & 3 & 660 & 285 & 115 \\
\hline 140 & 30 & 100 & 0 & & & 130 & & & 574 & & \\
\hline 140 & 45 & 50 & & & & 40 & 3 & 0 & 350 & 90 & 40 \\
\hline 140 & 45 & 100 & & & & 0 & & & 265 & & \\
\hline 140 & 60 & 50 & & & & 24 & 0 & 0 & 150 & 50 & 34 \\
\hline 140 & 60 & 100 & & & & 0 & & & 75 & & \\
\hline
\end{tabular}

Note - Blank boxes are cases that were not analyzed because shorter ventilation or storage times for a given set of waste package and drift spacings were found to be acceptable. 

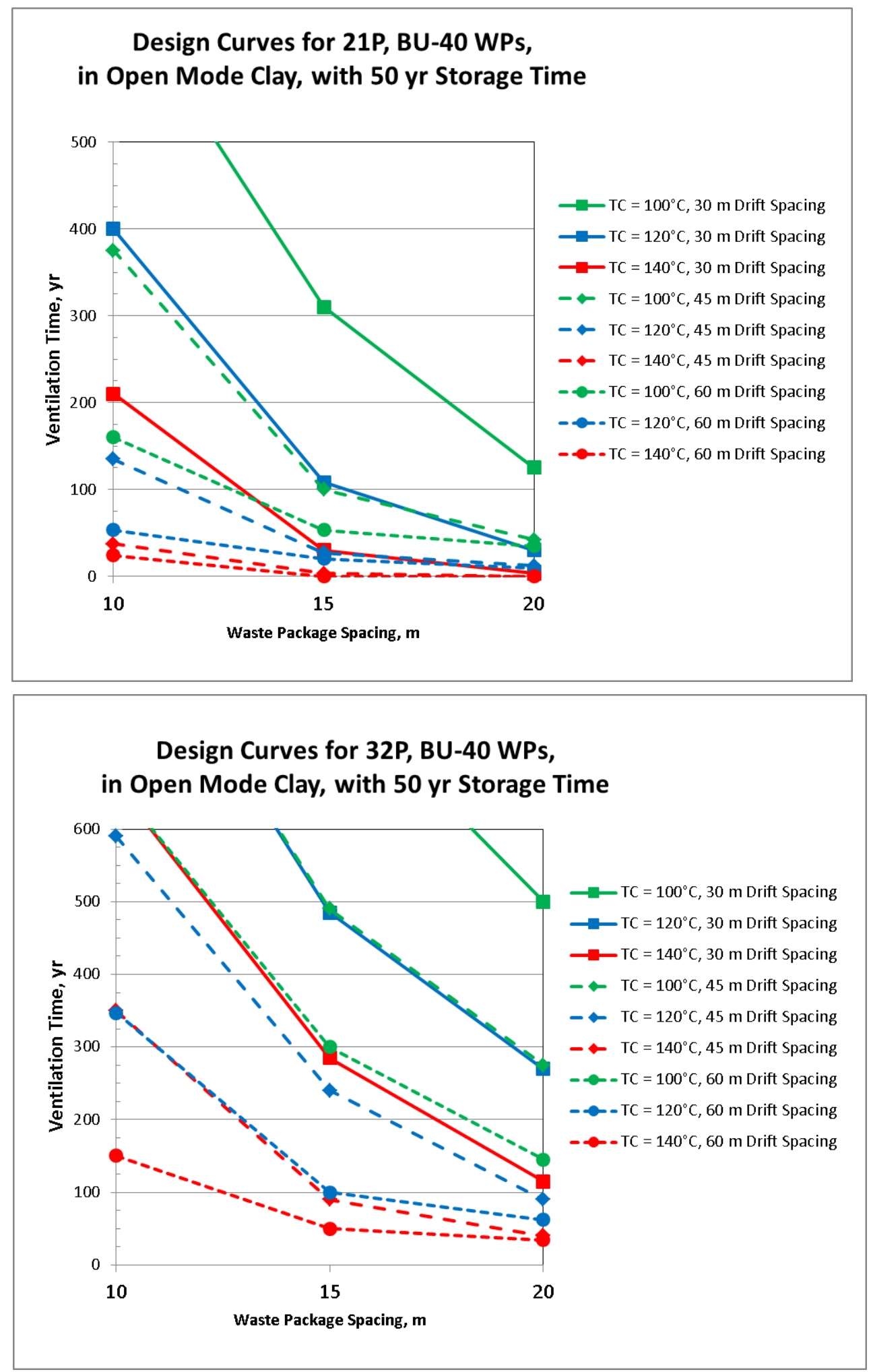

Figure 1 - Graphical Results from the 2013 IHLRWM paper for 21-PWR and 32-PWR waste packages 


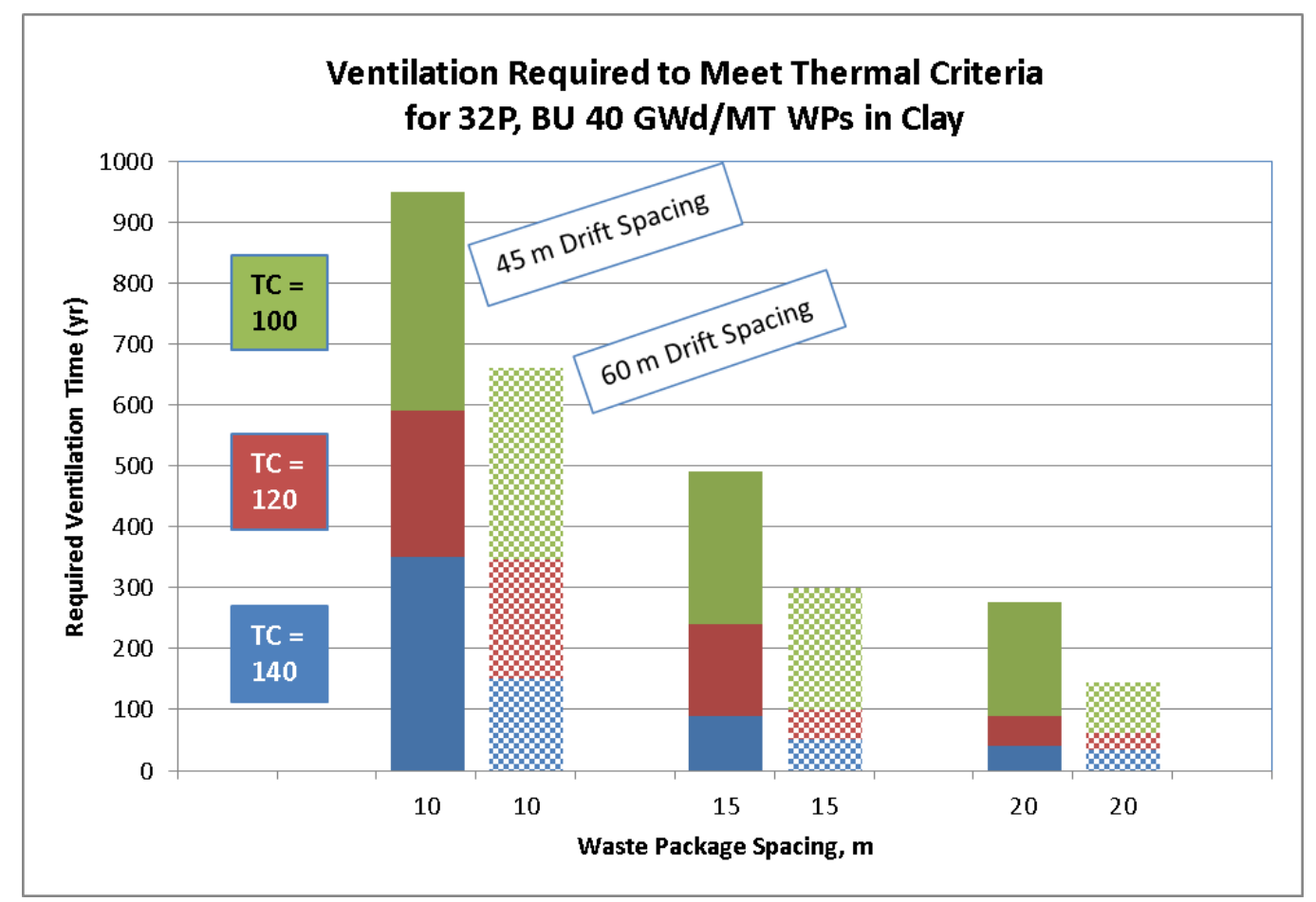

Figure 2 - Ventilation time required for a 32-PWR waste package stream in clay/shale - 2013 IHLRWM paper results

The colors of the stacked bars correspond to the temperature acceptance criterion evaluated for clay/shale at the drift wall. The checked pattern was used to differentiate the $45 \mathrm{~m}$ drift spacing cases from the $60 \mathrm{~m}$ drift spacing cases. This figure clearly shows how additional ventilation time is required as the temperature acceptance criterion becomes more restrictive. 


\section{Additional Base Cases Evaluated in this Report}

This report expands the analysis presented in Greenberg 2013a to address additional waste package and drift spacing options. Specifically, this report extends the analyzed maximum waste package spacing from 20 to $30 \mathrm{~m}$, and the maximum drift spacing from 60 to $90 \mathrm{~m}$.

The Mathcad thermal analytical model is documented in the DSEF Version 2.1 User's Manual (Greenberg 2013b). A modification of that model was developed for use in the report by adding an automated convergence loop to find required ventilation time for a given temperature acceptance criterion. The additional coding is shown in Appendix A.

A systematic approach balanced the contributions from the generic heat sources (central WP, axial neighbors, and lateral neighbors) to identify layout spacing combinations that are expected to provide an optimal tradeoff between excavation/backfill volumes and required ventilation duration. This recognizes that increasing the WP spacing increases excavation/backfill volumes more than increasing the drift spacing does. Further, a maximum ventilation duration of 150 years was imposed, in recognition of the effect of operations and maintenance cost on total system costs. When a cost model is implemented in DSEF, the use of the surrogate approach of balancing thermal contributions can be updated to be based on more direct metrics. Table 3 shows the allowable contribution ranges used in this study. The use of an axial neighbor contribution range of $20-50 \%$, compared to a lateral neighbor range of $15-40 \%$ recognizes that due to the stronger dependence of excavation/backfill volumes on waste package spacing (than on drift spacing) it is preferred to have more temperature contribution from the axial neighbors than from the lateral neighbors (which are characterized by the drift spacing). Green is used to depict contributions in the desired range, with yellow and red depicting contributions that are too small or too large.

The additional base cases evaluated are defined in the left panel of Table 4, with the required ventilation time shown in the right panel. Ventilation times greater than 150 years are shaded red. Table 5 shows heat source contribution percentages, using the color codes from Table 3. When all three contributions are in the desired range, and the ventilation time is less than the assumed limit, the design point (WP spacing and drift spacing) is considered to be in the "sweet spot" that meets the thermal criterion with a balance between excavation/backfill volumes and ventilation duration. The sweet spot can be recalculated on the basis of more direct metrics when the DSEF cost model is completed.

Table 3- Color code criterion for heat source contributions assumed for balancing the tradeoff between excavation/backfill volumes and required ventilation duration

\begin{tabular}{|c|c|c|c|}
\cline { 2 - 4 } \multicolumn{1}{c|}{} & $\begin{array}{c}\text { Yellow } \\
\text { if less } \\
\text { than }\end{array}$ & $\begin{array}{c}\text { Green if } \\
\text { between } \\
\text { low and } \\
\text { high }\end{array}$ & $\begin{array}{c}\text { Red if } \\
\text { greater } \\
\text { than }\end{array}$ \\
\hline Central WP Contribution & $30 \%$ & & $60 \%$ \\
\hline WPs in Adjacent Drifts & $15 \%$ & & $40 \%$ \\
\hline Axially Adjacent WPs & $20 \%$ & & $50 \%$ \\
\hline
\end{tabular}


Table 4 - Case numbers and required ventilation time results for new cases evaluated in clay/shale

\begin{tabular}{|c|c|c|c|c|c|}
\hline \multirow{3}{*}{$\begin{array}{l}\text { All cases with } \\
\text { t_store }=50 \text { years, } \\
\text { calculating required } \\
\text { ventilation time }\end{array}$} & \multirow{2}{*}{\multicolumn{2}{|c|}{$\begin{array}{l}\text { Case Number } \\
\text { Definition Table }\end{array}$}} & \multirow{2}{*}{\multicolumn{3}{|c|}{$\begin{array}{l}\text { 32-PWR waste package } \\
\text { DSEF base case } 229 \\
\text { Waste Package Spacing } \\
\end{array}$}} \\
\hline & & & & & \\
\hline & TC & Dr Sp & 10 & 20 & 30 \\
\hline \multirow{9}{*}{$\begin{array}{c}\text { Clay/shale } \\
\text { (sedimentary) }\end{array}$} & 100 & 30 & $229-1$ & 229-19 & $229-67$ \\
\hline & 100 & 60 & $229-3$ & 229-21 & $229-64$ \\
\hline & 100 & 90 & 229-37 & 229-49 & $229-61$ \\
\hline & 120 & 30 & $229-4$ & 229-22 & $229-68$ \\
\hline & 120 & 60 & $229-6$ & $229-24$ & $229-65$ \\
\hline & 120 & 90 & 229-38 & $229-50$ & $229-62$ \\
\hline & 140 & 30 & $229-7$ & 229-25 & $229-69$ \\
\hline & 140 & 60 & $229-9$ & $229-27$ & $229-66$ \\
\hline & 140 & 90 & 229-39 & $229-51$ & $229-63$ \\
\hline
\end{tabular}

\begin{tabular}{|c|c|c|c|c|c|}
\hline \multirow{3}{*}{$\begin{array}{l}\text { All cases with } \\
\text { t_store }=50 \text { years, } \\
\text { calculating required } \\
\text { ventilation time }\end{array}$} & \multirow{2}{*}{\multicolumn{2}{|c|}{$\begin{array}{c}\text { Required } \\
\text { Ventilation Time } \\
\text { Summary Table }\end{array}$}} & \multirow{2}{*}{\multicolumn{3}{|c|}{$\begin{array}{l}\text { 32-PWR waste package } \\
\text { DSEF base case } 229 \\
\text { Waste Package Spacing }\end{array}$}} \\
\hline & & & & & \\
\hline & TC & Dr Sp & 10 & 20 & 30 \\
\hline \multirow{9}{*}{$\begin{array}{c}\text { Clay/shale } \\
\text { (sedimentary) }\end{array}$} & 100 & 30 & 1450 & 513 & 236 \\
\hline & 100 & 60 & 660 & 146 & 86 \\
\hline & 100 & 90 & 335 & 106 & 80 \\
\hline & 120 & 30 & 950 & 270 & 81 \\
\hline & 120 & 60 & 347 & 63 & 46 \\
\hline & 120 & 90 & 148 & 57 & 44 \\
\hline & 140 & 30 & 662 & 116 & 35 \\
\hline & 140 & 60 & 156 & 34 & 24 \\
\hline & 140 & 90 & 83 & 32 & 23 \\
\hline
\end{tabular}

Note red colored cells have ventilation times exceeding 150 years.

Table 5 - Percentage contributions to peak wall temperature from the central WP, adjacent drifts, and adjacent WPs for clay/shale

\begin{tabular}{|c|c|c|c|c|c|c|c|c|c|c|c|}
\hline \multirow{3}{*}{$\begin{array}{l}\text { Drift wall } \\
\text { temperature } \\
\text { contribution } \\
\text { summary } \\
\text { table }\end{array}$} & \multirow{2}{*}{\multicolumn{2}{|c|}{$\begin{array}{c}\text { Temperature } \\
\text { Criterion and Drift } \\
\text { Spacing }\end{array}$}} & \multicolumn{9}{|c|}{$\begin{array}{c}\text { 32-PWR waste package } \\
\text { DSEF base case 229. Optimization Base Case Contribution Summary (\%) }\end{array}$} \\
\hline & & & \multicolumn{3}{|c|}{ WP Spacing $=10 \mathrm{~m}$} & \multicolumn{3}{|c|}{ WP Spacing $=20 \mathrm{~m}$} & \multicolumn{3}{|c|}{ WP Spacing $=30 \mathrm{~m}$} \\
\hline & TC & Dr Sp & $\begin{array}{l}\text { Central } \\
\text { WP }\end{array}$ & $\begin{array}{c}\text { Adj } \\
\text { Drifts }\end{array}$ & $\begin{array}{l}\text { Adj } \\
\text { WPs }\end{array}$ & $\begin{array}{c}\text { Central } \\
\text { WP }\end{array}$ & $\begin{array}{c}\text { Adj } \\
\text { Drifts }\end{array}$ & $\begin{array}{l}\text { Adj } \\
\text { WPs }\end{array}$ & $\begin{array}{l}\text { Central } \\
\text { WP }\end{array}$ & $\begin{array}{c}\text { Adj } \\
\text { Drifts }\end{array}$ & $\begin{array}{l}\text { Adj } \\
\text { WPs }\end{array}$ \\
\hline \multirow{9}{*}{$\begin{array}{c}\text { Clay/shale } \\
\text { (sedimentary) }\end{array}$} & 100 & 30 & 12 & 76 & 12 & 28 & 60 & 13 & 42 & 48 & 10 \\
\hline & 100 & 60 & 21 & 57 & 22 & 53 & 25 & 21 & 87 & 5 & 8 \\
\hline & 100 & 90 & 39 & 24 & 37 & 76 & 4 & 20 & 90 & 2 & 8 \\
\hline & 120 & 30 & 14 & 73 & 14 & 30 & 57 & 13 & 50 & 39 & 11 \\
\hline & 120 & 60 & 24 & 52 & 24 & 76 & 6 & 18 & 93 & 2 & 5 \\
\hline & 120 & 90 & 49 & 9 & 42 & 83 & 1 & 16 & 94 & 0 & 6 \\
\hline & 140 & 30 & 14 & 71 & 15 & 32 & 54 & 14 & 73 & 19 & 8 \\
\hline & 140 & 60 & 27 & 46 & 27 & 85 & 2 & 13 & 96 & 1 & 3 \\
\hline & 140 & 90 & 55 & 4 & 42 & 85 & 0 & 14 & 96 & 0 & 4 \\
\hline
\end{tabular}

Note - Colors were assigned prior to rounding the percentages.

Note - Small, non-bold font entries are from the long ventilation time cases (red in Table 4, right panel) 
Inside the sweet spot, the thermal constraint is met, and the peak temperature has balanced contributions from the central waste package, the axial neighbors, and the lateral neighbors. It is recognized that increasing the waste package spacing requires additional excavation volume proportional to the increased waste package spacing, and thus is more costly than increasing drift spacing which requires additional excavation volume proportional to the additional length of service drifts. Therefore, excavation volume will tend to be less when the axial neighbor waste packages make a higher contribution to peak temperature than the neighboring drifts (lateral neighbors). Appendix B begins the process of assembling data for the cost model that will more directly quantify those dependencies.

Figure 3 shows the results from Table 4 in histogram format. If the required ventilation time is greater than 150 years, then the results are displayed in the tables with a red background and white text in the right side panels of Table 4. This depiction recognizes that lengthy ventilation increases operating costs and at some point is socially unacceptable. From the right panel of Table 4, it is clear that $10 \mathrm{~m}$ waste package spacing results in excessive ventilation time (except for $90 \mathrm{~m}$ drift spacing and a 120 or $140^{\circ} \mathrm{C}$ temperature criterion at the rock wall). For $20 \mathrm{~m}$ waste package spacing, seven of the nine cases (combinations of drift spacing and temperature criterion) have acceptable ventilation times. For $30 \mathrm{~m}$ waste package spacing, eight of the nine cases have acceptable ventilation times. Thus, 17 of the 27 cases in Table 4 can be considered from the balanced contribution metric.

Table 5 shows the summary of heat source contributions to the peak drift wall temperature for the base cases evaluated in Table 4. Only one of seventeen acceptable cases from Table 4 met the balanced contribution metric ( $60 \mathrm{~m}$ drift spacing, $20 \mathrm{~m}$ waste package spacing, and $100^{\circ} \mathrm{C}$ temperature criterion), and thus is in the sweet spot. However, the coarseness of the spacing alternatives could skip over the sweet spot; this was considered likely given that a sweet spot point was found for the restrictive temperature criterion and none was found for the more permissive temperature criterion. Section 4 explores the design space with a finer grid of alternatives, to search for the sweet spot for each temperature criterion. 

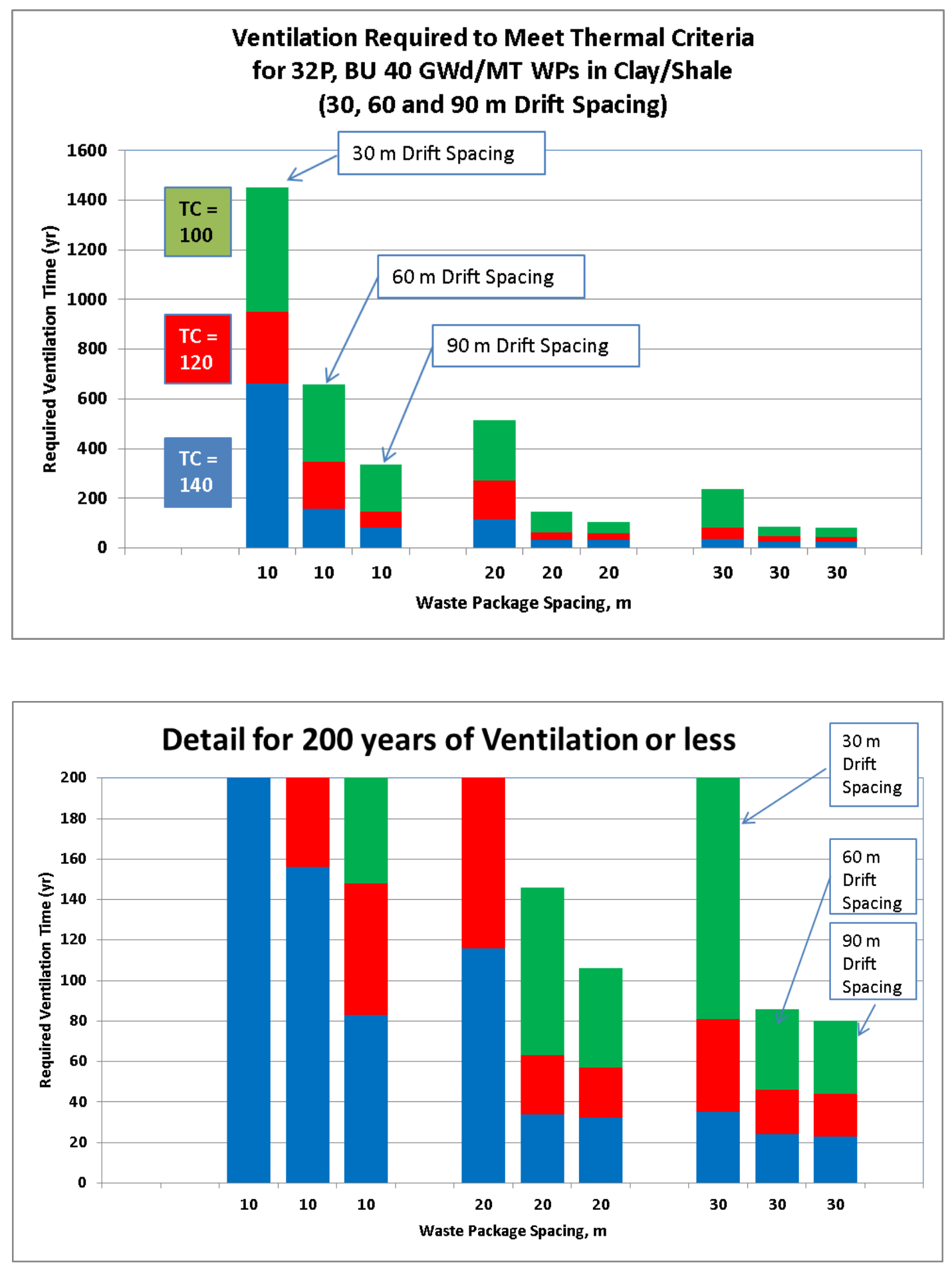

Figure 3- Required ventilation time as a function of temperature acceptance criterion, waste package spacing, and drift spacing.

Note that the lower panel in this figure focuses on ventilation times less than $200 \mathrm{yr}$. 


\section{Balanced Heat Source Contribution Evaluation}

The balanced heat source contribution, or "sweet spot" concept is described conceptually in Section 1 (Approach) and in detail in Section 3. This section applies that methodology in enough detail to visualize the sweet spot. Essentially, one uses a coarse grid of alternatives to find a point (drift spacing and WP spacing) that is in the sweet spot. Then, neighbor points (every $1 \mathrm{~m}$ of spacing) are evaluated until a point is reached at which the thermal contribution balance or ventilation time is outside the prescribed limits. The results of this process are shown in Figure 4. Note that the coarse grid from Section 3 found only one sweet spot point, but was not fine grained enough to find the three sweet spot regions.

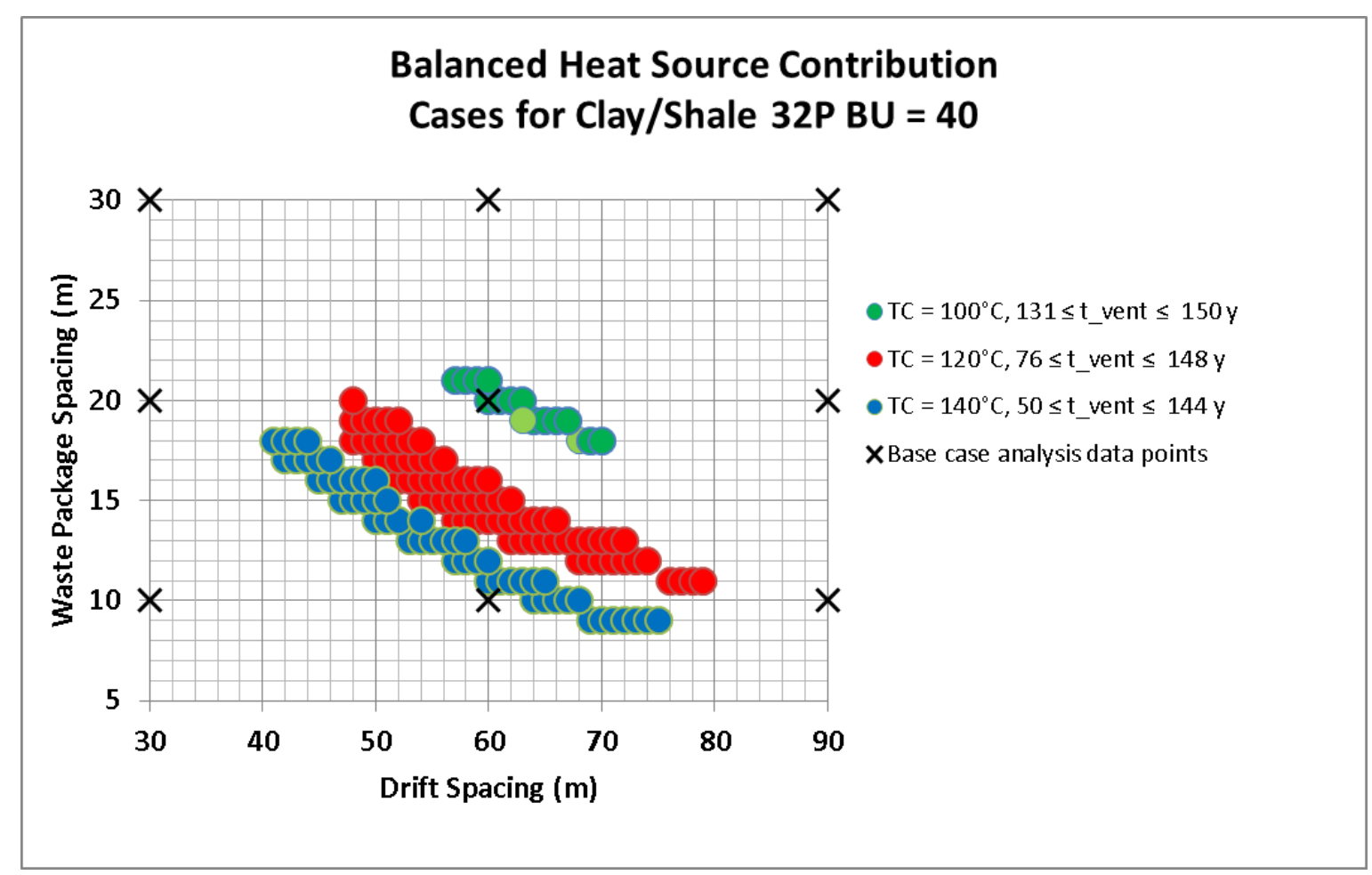

Note: The light green data points in the $T C=100^{\circ} \mathrm{C}$ cluster are those that require 150 years of ventilation.

Figure 4 - Balanced heat source contribution cases for $\mathrm{TC}=100,120$, and $140^{\circ} \mathrm{C}$ as a function of waste package and drift spacing.

The balanced heat source diagram showing sweet spots for $\mathrm{TC}=100^{\circ} \mathrm{C}, 120^{\circ} \mathrm{C}$, and $140^{\circ} \mathrm{C}$ extends over waste package spacing of roughly 9 to $21 \mathrm{~m}$, drift spacing of roughly 40 to $80 \mathrm{~m}$, and ventilation times of 50 to 150 years (after the end of 50 year surface storage time).

Figure 4 shows that the ranges of repository layout options that meet the balanced heat source criterion are more extensive for the more flexible thermal acceptance criterion of $\mathrm{TC}=120$ and $140^{\circ} \mathrm{C}$ than for the less flexible acceptance criteria of $\mathrm{TC}=100^{\circ} \mathrm{C}$. 
The following observations are found for the three thermal acceptance criterion considered in this study.

- $\mathrm{TC}=140^{\circ} \mathrm{C}$, waste package spacing values ranging from around 9 to $18 \mathrm{~m}$, and drift spacing values ranging from 41 to $75 \mathrm{~m}$, with required ventilation time ranging from 50 to 144 years

- $\mathrm{TC}=120^{\circ} \mathrm{C}$, waste package spacing values ranging from around 11 to $20 \mathrm{~m}$, and drift spacing values ranging from 48 to $79 \mathrm{~m}$, with required ventilation time ranging from 76 to 148 years

- $\mathrm{TC}=100^{\circ} \mathrm{C}$, waste package spacing values ranging from around 18 to $21 \mathrm{~m}$, and drift spacing values ranging from 57 to $70 \mathrm{~m}$, with required ventilation time ranging from 131 to 150 years

The trend is such that for more stringent temperature acceptance criteria, the longer the ventilation period required, and the smaller the acceptable range of waste package and drift spacing options that can meet a balanced heat contribution criteria.

Required Ventilation Time Results:

Development of the analysis cases to locate the sweet spot for different thermal criteria required a much finer grid of waste package and drift spacing than was previously examined in other studies. As a result, new insights can be gained regarding how required ventilation time varies with waste package and drift spacing. In particular, it is possible to see where the transition to diminishing returns occurs with respect to the benefit of required ventilation time being reduced as drift spacing is being increased. The diminished benefit of increased drift spacing corresponds to where the curves in Figure 5, Figure 6, and Figure 7 flatten. This provides valuable information for the decision maker who is responsible for making operational tradeoffs between excavation/backfill volumes and ventilation duration.

Figure 5, Figure 6, and Figure 7 show the required ventilation time for the design cases within the sweet spots identified in Figure 4, and extend a number of the waste package spacing curves to cover the full range of drift spacing that still meets the maximum ventilation time assumption of 150 years.

As seen on these figures, the cases that fall within the sweet spot are in the "knee" of the curves. On the left side of the knee, required ventilation time increases rapidly with decreasing drift spacing. On the right side of the knee, required ventilation time decreases more slowly with increasing drift spacing. As discussed above, the flattening of the curves on the right side of the knee corresponds to where diminishing returns occur with respect to how well increased drift spacing leverages a reduction in required ventilation time. 


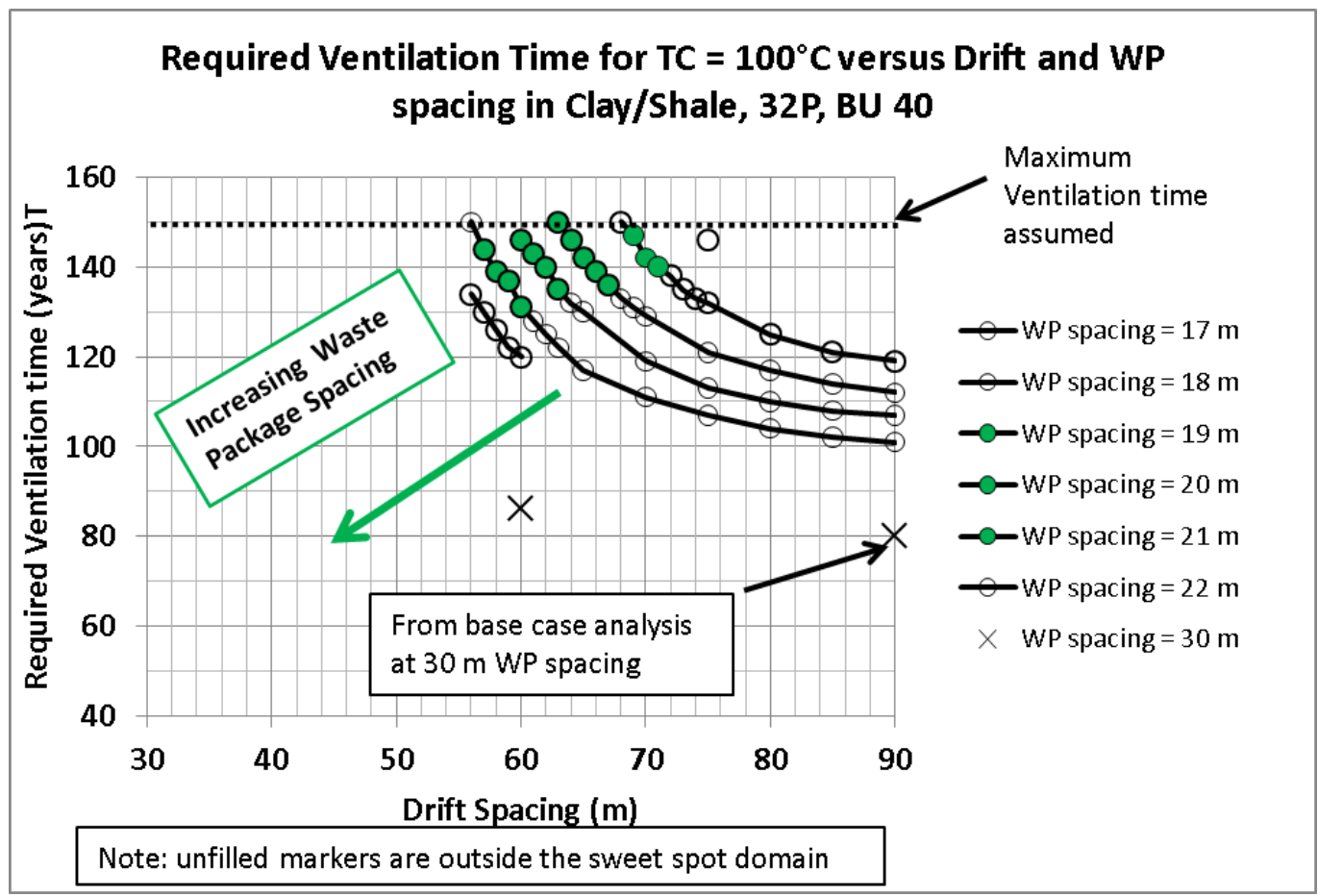

Figure 5- Required ventilation time in Clay/Shale for $\mathrm{TC}=100^{\circ} \mathrm{C}$ versus WP and drift spacing

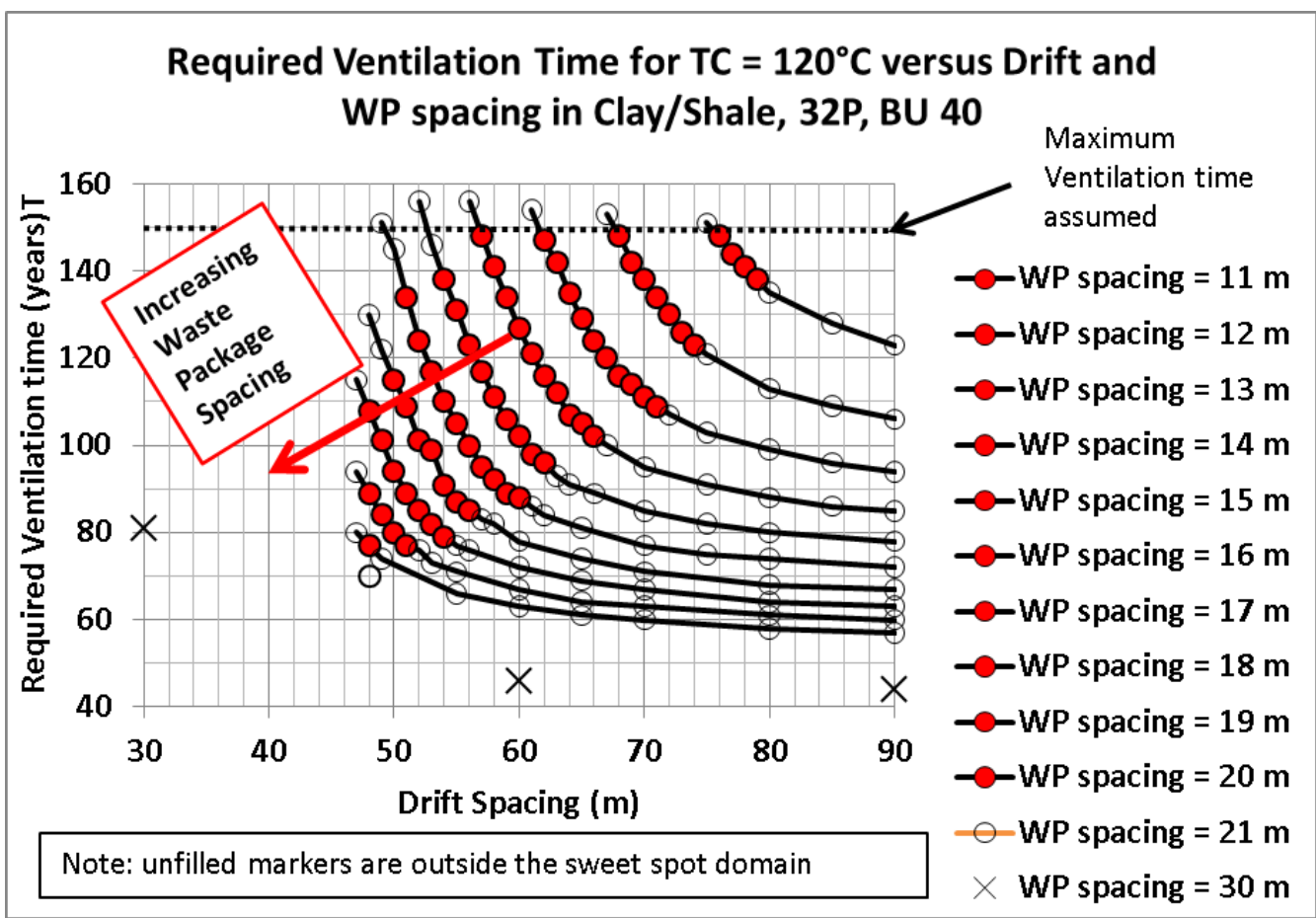

Figure 6- Required ventilation time in Clay/Shale for TC $=120^{\circ} \mathrm{C}$ versus WP and drift spacing 


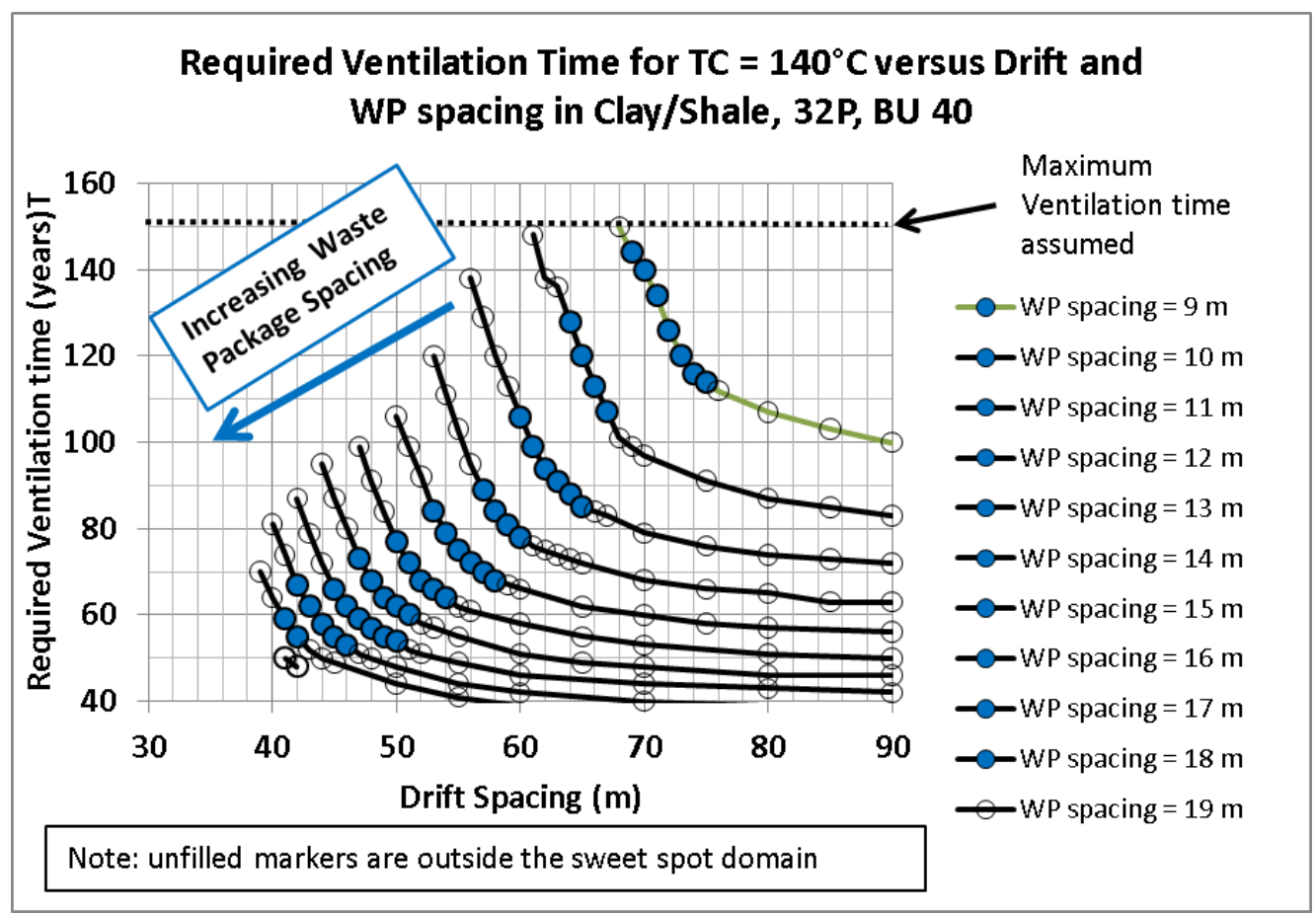

Figure 7 - Required ventilation time in Clay/Shale for TC $=140^{\circ} \mathrm{C}$ versus WP and drift spacing Note that the base case analysis for $30 \mathrm{~m}$ waste package spacing is off the scale of this plot (all points less than 40 years of required ventilation). 


\section{Results and Conclusions}

Section 2 analyzed the thermal performance for 12-PWR, 21-PWR, and 32-PWR waste packages with burnup of $40 \mathrm{GWd} / \mathrm{MT}$. Independent variables were the drift spacing and waste package spacing, in addition to the temperature criterion at the drift wall $\left(100,120\right.$, and $\left.140^{\circ} \mathrm{C}\right)$. Figure 3 shows that even a 32-PWR waste package can be emplaced with less than $150 \mathrm{yr}$ of ventilation if the temperature criterion is imposed at the drift wall rather than the buffer/backfill.

Section 3 extended the analysis to wider waste package and drift spacings, with similar results. At that point, the concept of a "sweet spot" was developed, in which large waste packages meeting the temperature criterion were emplaced with a combination of waste package spacing, drift spacing, and ventilation duration that would result in reasonable total system cost as well as operational duration within limits imposed from societal concerns. The features of the DSEF thermal model include separate calculation of the contributions of the central waste package (which is dominated by the burnup and size), the axial neighbors (dominated by the waste package spacing), and the lateral neighbors (dominated by the drift spacing). Allowable contribution ranges were developed as a surrogate for a full cost model. The ventilation time contributes to the operational cost as well. The results shown in Figure 4 define the sweet spot for each temperature criterion; with all points in the sweet spot meeting the surrogate cost model. This methodology enables the designer to select a range of designs with reasonable total system cost. 


\section{Future Considerations}

DSEF Version 3.0 will include a cost model based on the detailed cost model documented in Hardin

2012. Cost data for an open repository design in clay/shale is summarized in Hardin 2012 Table 5-1. However, operating and maintenance costs presented are a combination of results from both surface facilities and subsurface facilities. The DSEF Version 3.0 model would allow us to re-define the sweet spot in terms of optimizing repository total costs while meeting thermal constraints and ventilation time requirements. Appendix $B$ illustrates an important part of the process that will be incorporated in the DSEF cost model. 


\section{References}

Greenberg 2012a, H.R. Greenberg, M. Sharma, and M. Sutton, Investigations on Repository Near-Field Thermal Modeling, LLNL-TR-491099 Rev. 2, Lawrence Livermore National Laboratory, November 2012

Greenberg 2012b, H. R. Greenberg, M. Sharma, M. Sutton and A.V. Barnwell, Repository Near-Field Thermal Modeling Update Including Analysis of Open Mode Design Concepts, LLNL-TR-572252, Lawrence Livermore National Laboratory, August 2012

Greenberg 2013a, H. R. Greenberg, James A. Blink, and Montu Sharma, Using the Disposal Systems Evaluation Framework to Evaluate Design Tradeoffs, LLNL-CONF-614294, presented at the 2013 IHLRWM Conference, April 28 - May 3, 2013

Greenberg 2013b, Harris R. Greenberg, James A. Blink, Mark Sutton and Thomas J. Wolery, Disposal Systems Evaluation Framework DSEF Version 2.1 User Manual, LLNL-TR-629812, March 2013

Hardin 2011a, E. Hardin, J. Blink, H. Greenberg, M. Sutton, M. Fratoni, J. Carter, M. Dupont, and R. Howard, Generic Repository Design Concepts and Thermal Analysis (FY11), SAND2011-6202, Sandia National Laboratories, August 2011

Hardin 2012, E. Hardin, T. Hadgu, D. Clayton, R. Howard, H. Greenberg, J. Blink, M. Sharma, M. Sutton, J. Carter, M. Dupont and P. Rodwell, Repository Reference Disposal Concepts and Thermal Load Management Analysis, FCRD-UFD-2012-00219 Rev. 2, Sandia National Laboratories, November 2012

Hardin 2013, E. Hardin, T. Hadgu, D. Clayton, R. Howard, H. Greenberg, J. Blink, M. Sharma, M. Sutton, J. Carter, M. Dupont, and P. Rodwell, SNF Disposal Concepts for Small and Large Waste Packages, presented at the 2013 IHLRWM Conference, April 28 - May 3, 2013

Sutton 2011, M. Sutton, J. A. Blink, M. Fratoni, H. R. Greenberg, and A. D. Ross, Investigations on Repository Near-Field Thermal Modeling, LLNL-TR-491099 Rev. 1, Lawrence Livermore National Laboratory, December 2011 


\section{Appendix A - Mathcad Iterative Convergence Model}

The DSEF Version 2.1 User's Manual (Greenberg 2013b) documents a Mathcad model that is designed to facilitate both single case and up to 10 parametric study cases in a single Mathcad analysis document. That model was modified slightly to add a program loop at the end of the analysis which allows the program to automatically converge on a required ventilation time solution to a specified temperature acceptance criterion for the rock wall, within a specified number of degrees. This appendix provides the documentation for that model.

This Mathcad model also defines "areas" within the Mathcad document that can be collapsed or expanded to facilitate the use of the model in an iterative manner to rapidly allow the user to manually converge on an approximate solution before engaging the automatic convergence program loop.

In two or three guesses for required ventilation time for a given repository layout, waste form, and host rock combination, a user can generally get calculated temperature results close to, but still exceeding the temperature acceptance criteria. During this initial effort, the user sets the input variable ITERATE_OK := "NO", which will prevent the automatic convergence program loop from starting. Note that if the initially selected ventilation time yields a result below the temperature acceptance criteria, then the convergence loop will have no effect, since it will pass the acceptance test on the initial pass through the program loop. Therefore, the starting point must be a ventilation value that is too small to meet the temperature acceptance criteria.

After the initial manual convergence effort is performed, the user can set ITERATE_OK := "YES" and jump to the bottom of the Mathcad file to see the results. This convergence loop may take a while to run, depending on how close the manual convergence was, and what the convergence input value is (typically set as $1^{\circ} \mathrm{C}$ ).

One last step is required, and that is, given the final value of required ventilation time, go back to the top of the Mathcad file and replace the required ventilation time variable $\left(t_{\text {vent }}\right)$ with the solution value, and recalculate the Mathcad document. This step is required to update all of the plots to match the final required ventilation time solution.

The programming loop and additional calculations added at the end of the Mathcad model to automate convergence for specified temperature acceptance criteria is shown below. In this example the manual analysis stopped with a ventilation time of more than 63 years, and the automated loop was allowed to determine that 63 years of ventilation was sufficient. 
Appendix A - Mathcad Iterative Convergence Model

\section{OVERRIDE COUNTER AND STEP SIZE TO GET FINER CONVERGENCE ON THE ANSWER}

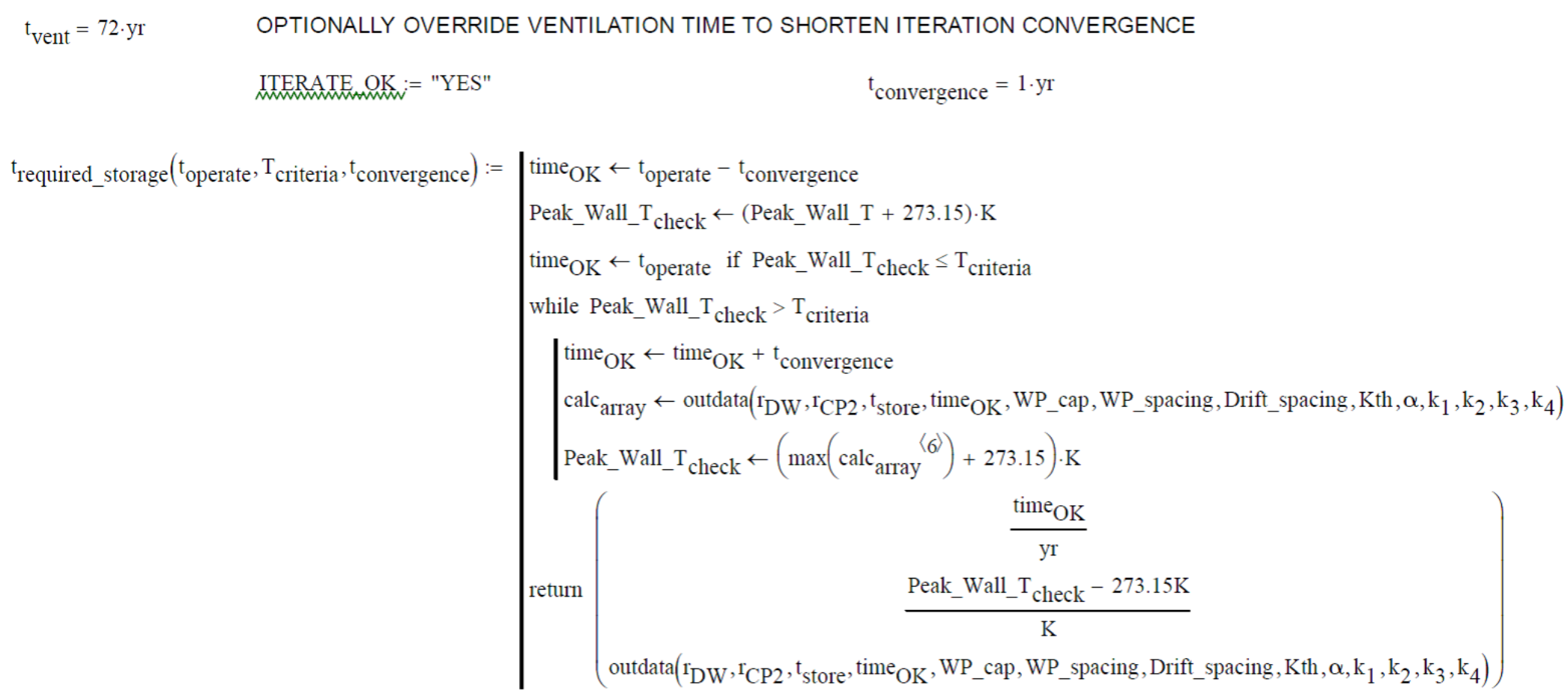


Appendix A - Mathcad Iterative Convergence Model

Result $:=\operatorname{stack}\left(\right.$ Title_array ${ }_{1}$, Final_array $\left.{ }_{3}\right)$

\begin{tabular}{|c|c|c|c|c|c|c|c|}
\hline & 1 & 2 & 3 & 4 & 5 & 6 & 7 \\
\hline 1 & "Parameter value: Base Case" & "'" & "'" & "m" & "'" & "'" & "'" \\
\hline 2 & "TooR (yr)" & "Wall $\Delta \mathrm{T}$ Central Line Src" & "Wall $\Delta T$ Adj Drifts" & "Wall $\Delta$ T Adj Pkgs" & "Compliance Point 2, C" & "Rock Wall Temp, C" & "EBS 1 inner Temp, C" \\
\hline 3 & 50 & 0 & 0 & 0 & 27.5 & 27.5 & 27.52 \\
\hline 4 & 55 & 35.579 & $1.907 \cdot 10^{-4}$ & 2.593 & 43.996 & 65.672 & 65.69 \\
\hline 5 & 60 & 34.943 & 0.028 & 4.854 & 46.949 & 67.326 & 67.343 \\
\hline 6 & 65 & 33.507 & 0.171 & 6.219 & 48.294 & 67.397 & 67.413 \\
\hline 7 & 70 & 31.898 & 0.441 & 7.103 & 48.969 & 66.942 & 66.957 \\
\hline 8 & 75 & 30.316 & 0.796 & 7.69 & 49.373 & 66.302 & 66.316 \\
\hline 9 & 80 & 28.814 & 1.196 & 8.08 & 49.609 & 65.59 & 65.603 \\
\hline 10 & 85 & 27.416 & 1.614 & 8.332 & 49.735 & 64.862 & 64.874 \\
\hline 11 & 90 & 26.118 & 2.031 & 8.432 & 49.786 & 64.081 & 64.093 \\
\hline 12 & 95 & 24.936 & 2.437 & 8.565 & 49.783 & 63.438 & 63.449 \\
\hline 13 & 100 & 23.83 & 2.831 & 8.593 & 49.749 & 62.755 & 62.766 \\
\hline 14 & 105 & 22.827 & 3.206 & 8.584 & 49.688 & 62.117 & 62.127 \\
\hline 15 & 110 & 21.9 & 3.56 & 8.539 & 49.603 & 61.499 & 61.509 \\
\hline 16 & 115 & 21.059 & 3.897 & 8.477 & 49.515 & 60.933 & 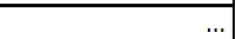 \\
\hline
\end{tabular}

Time_array :=(Final_array 3$)^{\langle 1\rangle}$

Peak_Temp(n) := max $\left[\left(\text { Final_array }_{3}\right)^{\langle\mathrm{n}\rangle}\right]$

Peak_Temp $(6)=119.612$

Peak_t(n) := lookup $[\text { Peak_Temp(n), (Final_array } 3)^{\langle\mathrm{n}\rangle}$, Time_array $] \quad$ Peak_t(6) $)_{1} \cdot \mathrm{yr}=155 \cdot \mathrm{yr}$

$\mathrm{nn}:=5 . .10 \quad$ Peak_results ${ }_{n n-4,1}:=$ Peak_Temp(nn) Peak_results ${ }_{n n-4,2}:=$ Peak_t(nn) ${ }_{1}$

Peak_results $=\left(\begin{array}{cc}93.584 & 440 \\ 119.612 & 155 \\ 119.642 & 150 \\ 208.389 & 135 \\ 208.389 & 135 \\ 208.389 & 135\end{array}\right) \begin{aligned} & \text { CP2 , time of } \\ & \text { peak } \\ & \text { Peak Wall T, time of } \\ & \text { peak } \\ & \begin{array}{l}\text { Peak EBS 1, time of peak } \\ \text { Peak EBS 2, time of peak } \\ \text { Peak EBS 3, time of peak } \\ \text { Waste Pkg T, time of } \\ \text { peak }\end{array}\end{aligned}$

Array_row_at_Wall_T_peak $:=\operatorname{match}\left[\right.$ Peak_Temp $\left.(6),(\text { Final_array } 3)^{\langle 6\rangle}\right] 1=22$

CP2_at_Wall_T_pk_t := $\left[\left(\text { Final_array }_{3}\right)\right]_{\text {Array_row_at_Wall_T_peak }}=84.552$

Central_WP_delta $:=\left[\left(\text { Final_array }_{3}\right)^{\langle 2\rangle}\right]_{\text {Array_row_at_Wall_T_peak }}=63.402$

Adj_Drift_delta $:=\left[\left(\text { Final_array }_{3}\right)^{\langle 3\rangle}\right]_{\text {Array_row_at_Wall_T_peak }}=8.096$ 


\section{Appendix A - Mathcad Iterative Convergence Model}

Adj_WP_delta $:=\left[\left(\text { Final_array }_{3}\right)^{\langle 4\rangle}\right]_{\text {Array_row_at_Wall_T_peak }}=20.615$

Result_Vector $:=\left(\frac{\text { WP_spacing }_{-}}{\mathrm{m}}\right.$ TC $\frac{\text { Drift_spacing }}{\mathrm{m}}$ Peak_results $_{6,1}$ Peak_results $_{6,2}$ Peak_results 2,1 Peak_results, 2,2 CP2_at_Wall_T_pk_t $\frac{{ }^{t} \text { vent_required }}{\text { yr }}$ Central_WP_delta Adj_Drift_delta Adj_WP_delta $)$

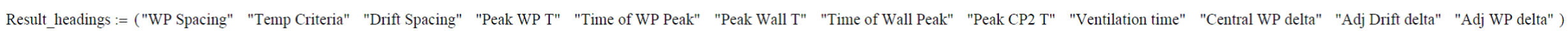

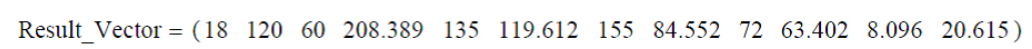

This is the result vector for transcription to the Excel case results tracking file

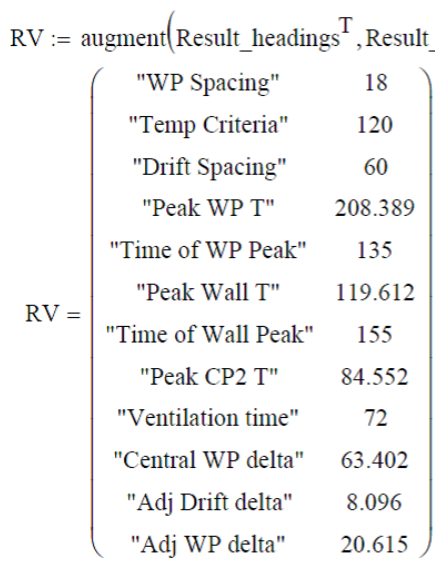

$\mathrm{T}_{\text {ambient }}=27.5 \cdot{ }^{\circ} \mathrm{C} \quad$ Contribution percentages at time of peak wall temperature

Percent_central_WP_delta $:=\frac{\text { Central_WP_delta }}{\text { Peak_Temp }(6)-\frac{\left(\mathrm{T}_{\text {ambient }}-273.15 \cdot \mathrm{K}\right)}{\mathrm{K}}} \cdot 100=68.831$

Percent_adj_Drift_delta $:=\frac{\text { Adj_Drift_delta }}{\text { Peak_Temp(6) }-\frac{\left(\mathrm{T}_{\text {ambient }}-273.15 \cdot \mathrm{K}\right)}{\mathrm{K}}} \cdot 100=8.789$

Percent_adj_WP_delta $:=\frac{\text { Adj_WP_delta }}{\text { Peak_Temp }(6)-\frac{\left(T_{\text {ambient }}-273.15 \cdot \mathrm{K}\right)}{\mathrm{K}}} \cdot 100=22.38$

Percent_central_WP_delta + Percent_adj_WP_delta + Percent_adj_Drift_delta $=100$ 


\section{Appendix B - Excavation Length versus Waste Package and Drift Spacing}

Figure 8 shows the normalized total repository excavation length as a function of both waste package and drift spacing over the full range of the values studied.

The methodology for calculating repository subsurface excavation length and excavation volume is described in Section 9, and Figures 20 and 21 of the DSEF Version 2.1 User's Manual (Greenberg 2013b). The calculation is straight-forward, and is based on a set of repository-level input assumptions provided on the DSEF INPUTS worksheet.

The specific repository-level input data used this report are shown in Table 6, and is based on a repository with a total capacity of 140,000 MTU. The example excavation length calculations were limited to the cases that assumed a waste package capacity of 32-PWR assemblies. The green colored labels in the right-hand column of Table 6 show the variable range names used within the DSEF Excel workbook.

Note that the DSEF cost calculations first evaluate a raw calculated set of values, and then apply cost contingency factors to account for cost uncertainties. However, since the objective in these calculations was to compare relative excavation lengths of the various repository design options, the values were all normalized to the base case having a waste package separation of $10 \mathrm{~m}$, and a drift spacing of $30 \mathrm{~m}$. Given this normalization approach, all of the contingency factors cancel out, and give the same result as a normalization based on the raw calculated values.

The raw calculated excavation lengths for the base cases analyzed for the clay/shale open repository layout are shown in Table 7, and the normalized values are shown in Figure 8. Note that the calculated excavation lengths include emplacement and service drifts, but do not include ramps and shafts. 
Appendix B - Excavation Length versus Waste Package and Drift Spacing

Table 6 - DSEF cost calculation input data for excavation length and volume calculations

\begin{tabular}{|c|c|l|}
\hline MTU per Repository & 140,000 & $<-$ Repository_MTU \\
\hline MTU per assembly & 0.47 & $<-$ Repository_avg_MTU_per_assembly \\
\hline
\end{tabular}

\begin{tabular}{|c|c|l|}
\hline WP/ (Emplacement Drift) & 15 & $<-$ Repository_WP_per_drift \\
\hline \# Emplacement Drifts / panel & 48 & $<-$ Repository_drifts_per_panel \\
\hline Radius $(m)$ of Access Main $\left(r_{\text {AM }}\right)$ & 2.75 & $<--$ Repository_access_main_r \\
\hline $\begin{array}{c}\text { Extra Spacing }(m) \text { at ends of Emplacement } \\
\text { Drift }\end{array}$ & 5 & $<-$ Repository_drift_extra_length \\
\hline Extra Spacing $(m)$ at ends of Access Main & 5 & $<-$ Repository_access_extra_length \\
\hline
\end{tabular}

\begin{tabular}{|c|c|c|}
\hline $\begin{array}{c}\text { Repository Design Mode for Cost Calculation } \\
\text { (Open or Enclosed) }\end{array}$ & OPEN & $<--$ Repository_design_mode \\
\hline
\end{tabular}

\begin{tabular}{|c|c|c|c|c|c|}
\hline $\begin{array}{c}\text { Waste Package } \\
\text { Capacity }\end{array}$ & $\begin{array}{c}\text { Waste Package } \\
\text { Length }(\mathrm{m})\end{array}$ & $\begin{array}{c}\text { WP Outer } \\
\text { Radius }(\mathrm{m})\end{array}$ & $\begin{array}{c}\text { WP Spacing } \\
(\mathrm{m})\end{array}$ & $\begin{array}{c}\text { Radius }(\mathrm{m}) \text { of } \\
\text { Emplacement Drift } \\
\left(\mathrm{r}_{\mathrm{DW}}\right)\end{array}$ & $\begin{array}{c}\text { Emplacement Drift } \\
\text { Spacing }(\mathrm{m})\end{array}$ \\
\hline 32 & 5 & 1 & 10 & 2.25 \\
\hline
\end{tabular}

Table 7 - Excavation length $(\mathrm{km})$ summary table

\begin{tabular}{|c|c|c|c|c|}
\hline \multirow{2}{*}{$\begin{array}{c}\text { Excavation Length }(\mathrm{km}) \\
\text { (for a 140,000 MTU repository) }\end{array}$} & $\begin{array}{c}\text { Base Case Required } \\
\text { Excavation Length } \\
\text { Summary Table }\end{array}$ & \multicolumn{3}{|c|}{$\begin{array}{c}\text { 32-PWR waste package } \\
\text { DSEF base case 229 }\end{array}$} \\
\cline { 2 - 5 } & $\operatorname{Dr~Sp~}(\mathrm{m})$ & 10 & 20 & 30 \\
\cline { 2 - 5 } & 30 & 115 & 201 & 288 \\
\hline \multirow{2}{*}{$\begin{array}{c}\text { Clay/shale } \\
\text { (sedimentary) }\end{array}$} & 60 & 133 & 220 & 307 \\
\cline { 2 - 5 } & 90 & 151 & 238 & 325 \\
\hline
\end{tabular}




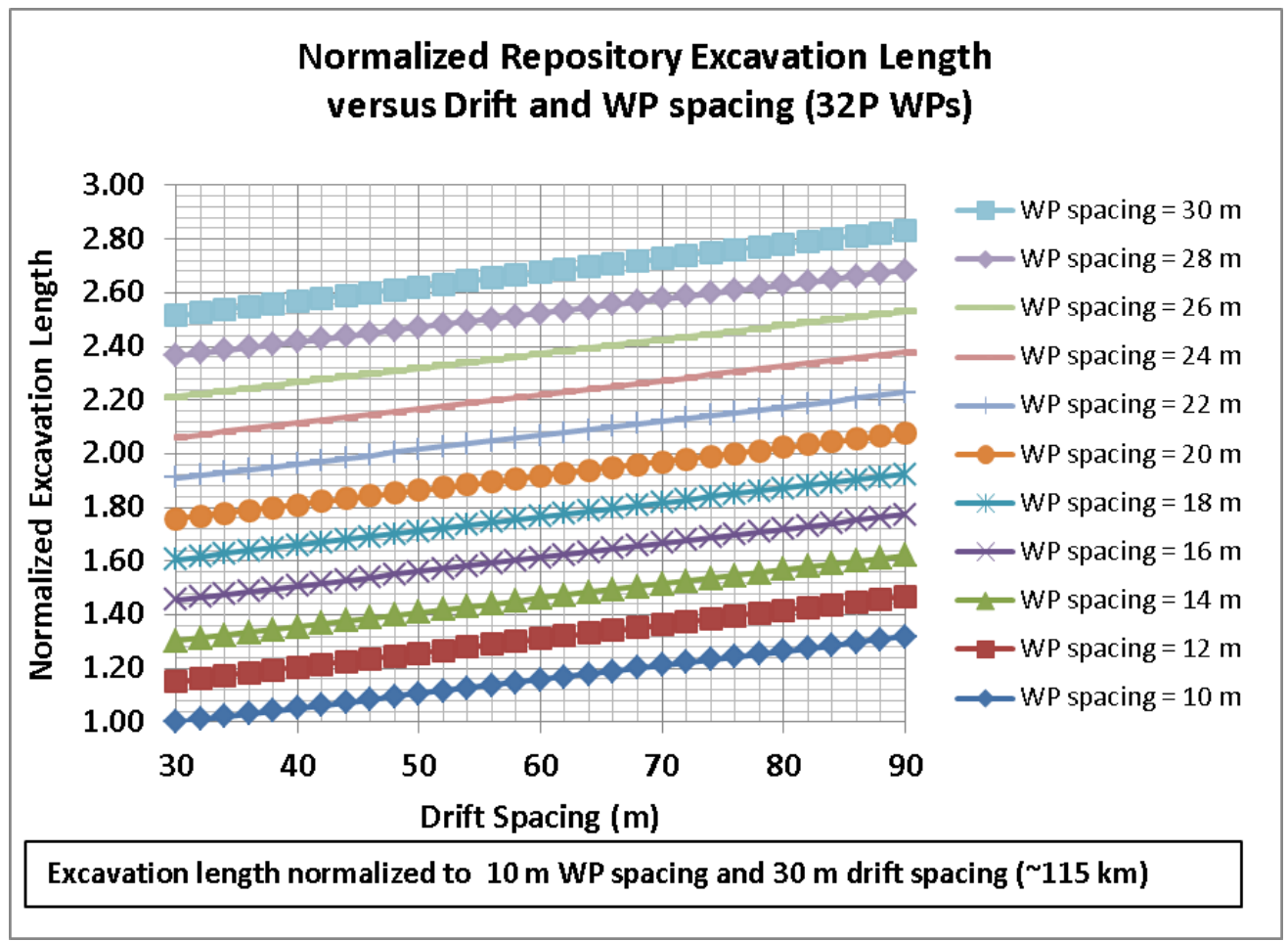

Figure 8- Normalized repository excavation length versus drift and WP spacing for 32-PWR waste packages Note that the excavation length includes emplacement and service drifts, but does not include ramps and shafts. 